\title{
Participatory Mapping of Mid-Holocene Anthropogenic Landscapes in Guyana with Kite Aerial Photography
}

By Isaac Shearn \& Michael J. Heckenberger

Coppin State University

Abstract- The nature and degree of human modifications of humid tropical forests in Amazonia have been widely debated over the past two decades. Many regions provide significant evidence of late Holocene anthropogenic influence by settled populations, but the antiquity of human interventions is still poorly understood due to a lack of earlier archaeological sites across the broad region, particularly pertaining to the mid-Holocene. Here we report on Amerindian occupations spanning the period from ca. 6000-3000 $\mathrm{BP}$ along the middle Berbice River, Guyana, including early evidence in Amazonia of cultural practices widely considered indicative of settled villages, notably terra preta or "black earth" soils, mound construction, and ceramic technology. These more settled occupations of the mid-Holocene initiated a trajectory of landscape domestication extending into historical times, including larger-scale late Holocene social formations. Collaborative research with local indigenous communities, including archaeological excavations, landscape mapping using kite based aerial photography, and three-dimensional photogrammetry, was designed to promote the decolonization of archaeological knowledge production and encourage indigenous ownership of Amerindian history and cultural heritage in Guyana.

Keywords: amazonia; archaeology; mid-holocene; human-natural systems; indigenous peoples.

GJHSS-D Classification: FOR Code: 160199

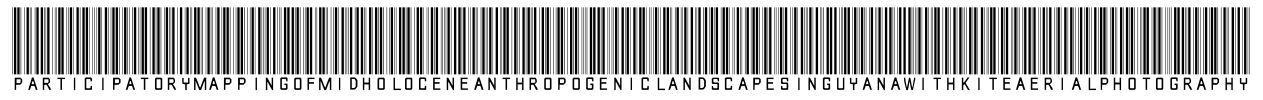

Strictly as per the compliance and regulations of:

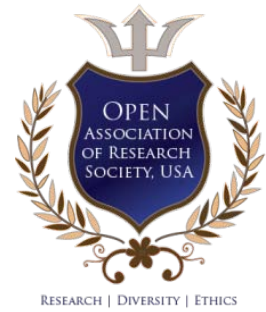

(C) 2020. Isaac Shearn \& Michael J. Heckenberger. This is a research/review paper, distributed under the terms of the Creative Commons Attribution-Noncommercial 3.0 Unported License http://creativecommons.org/licenses/by-nc/3.0/), permitting all noncommercial use, distribution, and reproduction in any medium, provided the original work is properly cited. 


\title{
Participatory Mapping of Mid-Holocene Anthropogenic Landscapes in Guyana with Kite Aerial Photography
}

\author{
Isaac Shearn ${ }^{\alpha} \&$ Michael J. Heckenberger ${ }^{\sigma}$
}

\begin{abstract}
The nature and degree of human modifications of humid tropical forests in Amazonia have been widely debated over the past two decades. Many regions provide significant evidence of late Holocene anthropogenic influence by settled populations, but the antiquity of human interventions is still poorly understood due to a lack of earlier archaeological sites across the broad region, particularly pertaining to the midHolocene. Here we report on Amerindian occupations spanning the period from ca.6000-3000 BP along the middle Berbice River, Guyana, including early evidence in Amazonia of cultural practices widely considered indicative of settled villages, notably terra preta or "black earth" soils, mound construction, and ceramic technology. These more settled occupations of the mid-Holocene initiated a trajectory of landscape domestication extending into historical times, including larger-scale late Holocene social formations. Collaborative research with local indigenous communities, including archaeological excavations, landscape mapping using kite based aerial photography, and three-dimensional photogrammetry, was designed to promote the decolonization of archaeological knowledge production and encourage indigenous ownership of Amerindian history and cultural heritage in Guyana.
\end{abstract}

Keywords: amazonia; archaeology; mid-holocene; human-natural systems; indigenous peoples.

\section{InTRODUCTION}

R esearch in the Berbice region of Guyana provides evidence for mid-Holocene human occupations with unexpectedly early dates for ceramics, settled villages, and agricultural innovations centered on landscape management (Shearn, et al. 2017; Whitehead, et al. 2010). This included earthen moundbuilding, wetland management systems, and soil engineering practices designed to improve the sandy and often impoverished savannah soils into productive anthropogenic soils, generally referred to as Amazonian dark earth or ADE (Woods, et al. 2009). These findings are indicative of large settlements and regional sociopolitical integration by ca. 5000-4500 BP, extending the antiquity of these cultural innovations associated with "formative" cultures in interior tropical forest settings of

Author a: Ph.D., Department of Applied Political and Social Science, Health and Human Services Building, Room 535, Coppin State University, United States. e-mail: isaacshearn@gmail.com

Author o: Ph.D., Department of Anthropology, 1112 Turlington Hall, University of Florida, Gainesville, United States. northern Amazonia (Arroyo-Kalin 2010; Burger and Rosenswig 2012; Oliver 2008).

Excavations at the Dubulay site and the mapping of associated earthworks provide a rare perspective on early settled communities and the proliferation of landscape domestication features associated with villages during the mid-Holocene in Amazonia. These document the deep antiquity and scale of human influences on these mosaic tropical forest ecologies, which do not conform to still popular views of sparse and ephemeral human interventions across most Amazonian forest environments (Barlow, et al. 2012; McMichael, et al. 2012; Piperno, et al. 2015). The six-millennial culture history of the Middle Berbice River documents substantial dynamic change in coupled human-natural systems, which has important implications for global debate regarding climate change and biodiversity, as well as indigenous cultural heritage.

\section{a) The Geographical and Historical Context of Moundbuilding in Guyana}

Although Amazonia was long viewed as the world's iconic pristine tropical forest, archaeology and historical ecology over the past two decades suggest substantial human influence, rivaling other major world forest regions in antiquity, scale and density of indigenous populations in pre-modern times (Clement, et al. 2015; Heckenberger and Neves 2009; Roosevelt 2013). These views emphasize long-term change in dynamic coupled natural-human systems, including substantial pre-colonial modifications of the natural environment, climate change and catastrophic postcontact depopulation (Balée and Erickson 2006; Denevan 2001; McEwan, et al. 2001; Rostain 2012; Schaan 2012). Most regional specialists agree that parts of the region supported substantial socio-historical diversity, including cultural innovations and change similar in antiquity and scale to other parts of the Americas, including diverse forager occupations and initial plant domestication by the early Holocene, settled agricultural technologies by the middle to late Holocene and densely settled regional polities during late precolonial times.

The cultural history in most areas remains poorly resolved, notably for initial settled human occupations during the middle Holocene (ca. 6000-3000 
BP). Our findings document the deep antiquity of cultural innovations widely associated with settled communities and associated landscape modifications, including ceramics, terra preta (ADE) and major earthen mounds. Early mound-building marks the onset of an initial or "formative" period of settled village life and regional organization (5000-4000 BP), roughly contemporaneous with developments in US Southeast, Mesoamerica and Andean areas (Arroyo-Kalin 2010; Burger and Rosenswig 2012; Oliver 2008). Humanmade mounds and early ceramics are seen to indicate the transition to settled or semi-settled communities, although typically associated with shell mounds across northern South America (Roosevelt, et al. 1991; Roosevelt 1995). The scale and uniqueness of the Dubulay mound suggests that this site was more than a structurally elaborated autonomous village and indicates participation in and some degree of integration within a regional social group, suggested by similar age $\mathrm{ADE}$ deposits and diagnostic Dubali ceramics at the Hitia and other sites downstream from Dubulay. Major public constructions at the Dubulay site from ca. 5000 to 4600 $\mathrm{BP}$ suggest that changes in social and symbolic systems, notably public ritual, were equally as important as techno-economic change tied to food procurement in the transition to more settled life (Burger and Rosenswig 2012; Flannery 1976; Lathrap 1977). The proliferation of mound sites radiating from the middle Berbice represents a pattern of agricultural innovation that parallels innovations in ceramic stylistic technologies Shearn, et al. 2017). We propose that these innovations are associated with a shift toward more communal landscape management projects.

The mid-Holocene occupations document changes in subsistence strategies related to ADE formation, often taken to indicate early agricultural practices (Oliver 2008). The ADE deposits at the Dubulay and Hitia sites suggest domestic refuse disposal and probable associated house gardening Arroyo-Kalin 2010), the role agricultural crops played in subsistence systems during this period awaits paleoethnobotanical and geochemical studies of ADE deposits. A variety of plants used by historically known Arawak language-speaking groups were widely available by mid-Holocene times across the broad region, including early domesticates, such as manioc and maize, but plant use likely focused on the large repertoire of useful non- and semi-domesticated species and diversified production systems (Clement, et al. 2010; Piperno and Pearsall 1998). The degree to which house gardening and other casual horticulture practices were supplemented by more extensive nondomestic farming practices, including construction and cultivation of savanna mounds, is uncertain. Forest slash-and-burn gardening and common use of small agricultural mounds are known for late Holocene populations (Rostain 2008a; Rostain 2010), but cannot be attributed to the mid-Holocene occupations.

The enduring occupation and scale of modification reflected in the mounds, associated with early ceramic technologies in the region, and the ADE soils that were used to construct it, indicate significant landscape modification in mid-Holocene times. In Guyana, this appears to have involved the management of diverse forest, wetland and savanna resources, but did not necessarily involve clear-cutting of forests for gardening. These initial signs of settled life appear during the mid-Holocene Warm Period (Pachauri, et al. 2014; Prado, et al. 2013). Environmental changes due to climate clearly would have impacted human-nature interactions, particularly the warmer and wetter conditions of northern South America (Silva Dias, et al. 2009), and more intensive management of forest resources and plant cultivation during this time may have enhanced forest cover in the warmer climates of the mid-Holocene (Carson, et al. 2014). These occupations clearly represent a substantial footprint on the local landscape, including significant changes in human interactions with plant and animal populations, as reflected in ADE. At the very least, the complexity of the mid-Holocene landscapes of the Middle Berbice attest that detailed archaeological survey and mapping is necessary to investigate pre-colonial and historic socio-ecological heterogeneity and dynamic change, including documented intra- and inter-regional variation. Moundbuilding is well documented during the lateHolocene along coastal regions of the Guianas, however, the origins of the practice and extent to which such practices were common, remain open questions for the development of diverse agricultural practices in Amazonia (Clement, et al. 2015; Denevan 2001; Denevan 2003; Iriarte, et al. 2020; McKey, et al. 2010; Rostain 2008a; Rostain 2008b; Rostain 2010; Rostain 2012). Artificial mounds are reported in coastal regions north of the Guiana plateau in areas dominated by Arawak-speaking peoples, often associated with the Mabaruma sub-tradition (Saladoid-Barrancoid tradition) (Evans and Meggers 1960; Plew 2005; Rostain 2012; Williams 2003). In addition to pre-colonial agricultural raised fields (Iriarte, et al. 2010; Rostain 2010), recent research documents many different kinds of mound landscapes of natural origin, including round mounds (Renard, et al. 2012b). The presence of naturally occurring mound features in seasonally flooded savanna landscapes has been well documented, and important recent research adopts a historical ecological approach to investigate the feedback loop created between anthropogenic inputs and other ecosystem "managers" such as termites and earthworms (Iriarte, et al. 2010; McKey, et al. 2014; McKey, et al. 2010; Renard, et al. 2012a; Renard, et al. 2012b). In Brazil, similar mound fields, or campos de murundus were 
evaluated to test hypotheses about their construction evaluating whether termite construction or differential erosion was likely to cause the formation of mounds (Silva, et al. 2010). They conclude that erosion was more likely than termite nesting, but an anthropogenic origin was not considered. While it cannot be confirmed conclusively that the small, round mounds tested in the middle Berbice result from human intervention, there are a range of other earthen features that are clearly cultural, including large linear single mounds, large village mounds, and an excavated ditch around a circular mound interpreted as a platform for a domestic structures. Terminal pre-colonial to early historic agricultural populations developed farming in areas away from major habitation sites, including historical use of mounds by contemporary Arawak communities in the Berbice (Whitehead, et al. 2010).

\section{b) The Survey Area: Middle Berbice, Guyana}

The study area is located approximately $80 \mathrm{~km}$ from the mouth of the Berbice River at the junction with Wiruni Creek, the location of the modern Wiruni village, but the distance by boat is about $160 \mathrm{~km}$ along the winding Berbice River (Figure 1). As one travels upstream closed tropical rainforest dominates the landscape, but by the middle reached of the Berbice River downstream to mouth environments are a mixture of forest areas, including low-lying forests along the river and its tributaries, and open savannah. These savannahs often include small forest islands in the study areas, which may also have resulted from past management strategies, as noted elsewhere in such transitional settings (Posey and Balée 1989). Models of the topography surrounding Dubulay were developed to predict where water channels would have flowed under wetter late-Holocene conditions (Prado, et al. 2013) to further contextualize the anthropogenic features with respect to the dynamic landscape.

In total, six areas were mapped using the kitebased photography technique. Four of the areas are located on Dubulay Ranch property, including the ranch area itself (the location of 2011 University of Florida excavations), two fields of agricultural mounds (referred to here as Mound Group 2 and 3), and the well-known, yet poorly understood linear mounds west of the ranch. Two additional areas along the Wiruni Creek were mapped; Red Hill, which is located directly on the creek, and Matara, which is located approximately $1 \mathrm{~km}$ north of the creek, beyond the historic (Dutch) Fort Nassau.

\section{Methods}

Here we adopt an archaeological and ethnographic approach augmented with photogrammetric and spatial analytical methods in order to associate specific mounds formations with other evidence of human occupations. After first being identified by Joe Singh in 1986, and identified as Amerindian in origin, preliminary archaeological excavations in the study area were undertaken in 2009, followed by intensive fieldwork in 2011. In 2014 a return trip was made to complete the ceramic analysis of the 2011 materials with local participants in Guyana and to map the mound sites that were associated with known archaeological sites with the Wiruni/Matara indigenous community. The results of the archaeological excavations and the mapping of the mound sites are discussed here.

\section{a) Excavations of Village and Domestic Mound Contexts}

Research conducted in a $\sim 400 \mathrm{~km}^{2}$ study area along the middle Berbice identified 10 pre-colonial sites, including the large (5-8 ha) Dubulay and Hitia sites, situated on high (20-25 m), non-inundated river bluffs. Site survey was conducted along the Berbice River, Wiruni Creek and Kaikuchen stream and involved extensive walk-over inspection and soil augers $(8 \mathrm{~cm}$ bucket) and test pit excavations (50-x-50-cm and 1-x-1-m).

Fieldwork at the Dubulay site included extensive surface inspection and soil augers to determine site boundaries; hand-excavated trench excavations were positioned to bisect mound 1 and test adjacent areas in eastern portions of the site and in central site areas; excavation units $(1-x-1-m)$ were placed along trench walls and in western portions of the site (Heckenberger, et al. 2012). Trench 1 (25 m), adjacent to a 1-m-x-50-cm test pit, and trench $4(10 \mathrm{~m})$ provided cross-sections of the deepest portions of the artificial mound, maximally extending to $\approx 4.0 \mathrm{~m}$ deep. Two $1-\mathrm{x}-1-\mathrm{m}$ units were excavated from the west wall of trench 1 to depths of 3.6 $\mathrm{m}$ (N966/W998) and $2.6 \mathrm{~m}$ (N978/N998). One excavation unit (1-x-1-m) and two block excavations (4$\mathrm{x}-4-\mathrm{m})$ were conducted along trench 5 to expose whole ceramic vessels and associated domestic areas adjacent to the northern part of the mound 1. Two 1-x-1$m$ units were excavated in western site areas (Locus 2).

Excavation of units $1-x-1-m$ and greater was conducted in 50-x-50-cm horizontal sub-units, or quadrants, and in $10 \mathrm{~cm}$ arbitrary vertical levels using sharpened shovels, trowels, and fine-grain excavation tools. All sediment was passed through $0.65 \mathrm{~cm}$ mesh hardware cloth. After excavation, all units were profiled, photographed, and "grab samples" (81 samples of > $500 \mathrm{~g}$ ) were trowel-collected from all discernable strata. Soil sampling using an $8 \mathrm{~cm}$ diameter bucket auger was conducted across the site to $2 \mathrm{~m}$ depth and changes in sediment composition and color were noted, including along the mound apex to determine length and variation in depth.

\section{b) Participatory Mapping with Three-Dimensional Photogrammetry \\ In order to contextualize the findings from the Dubulay site with features of the surrounding landscape- including forest islands and dry creeks and drainages,}


and round domestic mounds, linear earthworks, and several clusters of round conical mounds produced by humans and or soil engineers in terminal mid-Holocene to mid-Holocene times-reconnaissance teams scouted and investigated many nearby areas in 2011 that were then revisited in 2014 to produce better maps of the features.

In 2014, the method utilized for mapping the mounds consisted involved participation of local community members to gain insight into the location and ecological conditions of mound areas. The team of participants from the local communities shared their extremely detailed local ecological knowledge helping us to rapidly identify locales with mounds and target those areas without having to survey random fields in search of mounds. The aim of kite mapping was to generate high resolution three-dimensional maps of the mound areas (Aber, et al. 2002). We used a pair of $7 \mathrm{~m}$ and $9 \mathrm{~m}$ delta kites to fly cameras over mound areas to capture aerial imagery. For this project, we used a kite for two main reasons. We wanted the mapping of the mounds to be a participatory and educational project for local communities to get involved with, and because it represents the lowest-cost solution, making it the most widely accessible and easiest entry point into the method. We cannot ignore the affect that a kite, as opposed to a drone, has on the perception of our research when abroad. The tradeoff is not in terms of the quality of data returned, but in the ability to get consistent coverage of broad areas. For that reason, our results were often irregularly shaped slices of landscape that more or less captured all mounded areas in a contiguous landform. The images were processed using Agisoft PhotoScan to utilize stereoscopic photogrammetry to produce a high-resolution digital terrain model from which a digital elevation model (DEM) and an orthomosaic were constructed.

\section{Results}

\section{a) Archaeological Excavations at Dubulay Ranch}

Four mid-Holocene components were defined at Dubulay (Shearn, et al. 2017): 1) initial stratified occupations of mobile or semi-settled populations, pre$6000 \mathrm{BP} ; 2)$ initial settled occupations, including ADE and ceramics, ca. 6000-5000 BP; 3) construction of a major ceremonial mound, ca. 5000-4500 BP; and 4) continued occupations in areas around the mound until ca. 3,000 (Figure 2, Table 1). Occupations continued through the late Holocene, including possible mound farming in savanna areas near the Dubulay site by ca. 3000-2000 BP, and historically and archaeologically documented occupations by Berbice Arawak communities reported from the early 1600 s to the present (Whitehead, et al. 2010).

Early mid-Holocene occupations, ca. 6000-5000 $\mathrm{BP}$, were identified as thin stratified anthrosols $(\sim 5-10$ $\mathrm{cm}$ thick), notably darker than basal (pre-cultural) compact clays and intervening sterile strata in western portions of the Dubulay site. They were encountered 80$150 \mathrm{~cm}$ deep, beneath a thick ADE deposit, and contained sporadic carbonized botanical remains and ceramics (Figure 2), suggesting repeated use of domestic areas with intervening natural eolian deposition. A basal date of $6130 \mathrm{BP}$ was obtained from the base $(60-80 \mathrm{~cm})$ of the dark ADE anthrosol (20-80 $\mathrm{cm}$ ), which contained abundant ceramic and organic remains. Such pronounced ADE midden deposits are commonly attributed to household disposal activities, reflecting more enduring occupations and producing rich soils for house gardening (Arroyo-Kalin 2010; Woods and McCann 1999). A charcoal-rich layer (60-70 $\mathrm{cm}$ ) in N1390/W1319 that contained >10 small ceramic sherds was dated to $5825 \mathrm{BP}$. N1390/N1319 was excavated adjacent to the 2009 test pit that produced a $\mathrm{C}^{14}$ age estimate of $5140 \mathrm{BP}$ from the lowest deposits containing cultural remains $(60-70 \mathrm{~cm})$. An early ADE midden (4710 BP) was also identified along the western bank of the Berbice River at the Hitia site, roughly $20 \mathrm{~km}$ downstream.

\section{b) Village and Ceremonial Mound}

By 4650 BP, a large river bluff mound was constructed at the Dubulay site, which distinguished it from Hitia and other sites in the study area. The earthen mound measures $\sim 200 \times 50 \mathrm{~m}\left(\sim 20,000 \mathrm{~m}^{3}\right.$ of moved earth) along the bluff, which plunges an additional $\sim 25$ $\mathrm{m}$ to the river channel, giving the mound an imposing vertical face from the river, with largely intact stratigraphy to a maximal depth of over $4 \mathrm{~m}$ at the mound apex (Figure 2). Radiocarbon dates suggest it was constructed during a relatively short time, perhaps a few generations. The mound was created by repeated, highly patterned construction episodes, preserved in 39 alternating "couplets" of lighter, thicker and sandier layers capped with darker ADE. Large ceramic fragments were often orientated horizontally within darker micro-strata, suggesting intentional capping and compaction over light, sandy layers to enhance structural stability. Basal light layers are mottled and extremely compact due in part to mixing with underlying clay-rich natural strata. Ceramics were associated with all micro-strata, including the deepest, but were much denser in mid- to upper dark layers.

The stratigraphy of the mound was fairly continuous across higher portions of the mound, northern portions of trench 1 and across trench 4 , including well stratified mound deposits $(>50 \mathrm{~cm})$, dating to 4690-4614 BP, and mixed upper strata, characterized by a homogeneous dark macro-stratum created by later pre-colonial and historic hoe and mechanized agriculture and construction activities. Lower stratified strata are pinched off toward southern portions of Trench 1. The mound is composed of 
substantial ADE, although not from in-situ domestic waste disposal or composting behavior. The extremely dark color, oily texture and ceramic density of these charcoal-infused deposits document substantial local ADE formation, which were intentionally redeposited as mound construction elements. The associated ceramics assemblage is also notable for the large quantity of sherds in mound fill, indicative of more than casual production. The construction of the mound also informs us about other aspects of mid-Holocene cultural industries, notably the relation between early ceramic technologies and formation of highly modified ADE.

A technofunctional and stylistic analysis of ceramic remains excavated in 2011 was conducted in 2014 (Shearn, et al. 2017), so only a brief description of the ceramics is presented here. There were two main features of the ceramic assemblages that were identified in the analysis that required explanation and were relevant to the proposed interpretation of the relationship between village sites and mound sites. These included the sequence of stylistic innovation that began during construction of the mound consisting of small- to medium-sized coiled, low-fired vessels with predominately sand tempers decorated by small appliqué strips in simple geometric designs giving way rapidly to more complex, or cross-hatched designs on the rims. The second feature of the assemblage we sought to explain was the apparently intentional deposition of five serving vessels in a cache on the outskirts of the Dubulay Village site. In 2017, the authors put forward the hypothesis that both of these innovative features of the ceramic assemblage were related to innovations in agriculture, a hypothesis we expand upon here with an analysis of innovations in relationships with the landscape.

\section{c) Linear Mound Group}

The linear mound features are located approximately 3-4 km west of the 2011 excavations, and just north of the Wanyabo creek, an excellent source of fresh water. Although several of the linear features can be seen in the map provided above, several are difficult to make out because of the low vertical profile that many of the linear mounds feature, as well as the high grass cover both on and off the mounds. However, when looking at the digital elevation model (generated with the same software) the linear features are easier to resolve and exhibit three distinct patterns. (Figure 3). 1) Linear, near parallel mounds that potentially radiate from a similar point, 2) S-twist linear mounds, and 3) arcing parallel linear mounds. The presence of linear and semicircular earthwork features in savannah areas closely associated to the mound at Dubulay lends support to the interpretation of nearby circular mounds as having their origin in similar practices.

\section{d) Surrounding Mound Groups}

Investigations conducted in savanna and scrubland areas adjacent to the pre-colonial occupation sites in forested areas along the Berbice River and Wiruni Creek documented a variety of anthropogenic features, including small residential sites, forest islands, as well as low conical mounds of possible human origin situated along the slopes rising from stream-beds, several of which are seasonally dry.

\section{i. Mound Group 2}

We were led to Mound Group 2 by Reard, the manager at Dubulay Ranch. Reard was an expert source of information about the mounds, the landscape surrounding those mounds, and the recent history of land-use that may have affected the distribution and preservation of mound sites. Mound Group 2 is located on a gentle slope, which, although truncated by the tree line, leads down to a creek bed to the west (Figure 4). Mound group 2 is a very typical example of the types of locations we came to find the majority of the mound sites. Notably, the mounds were found consistently along gently sloping ground rising from a pond or creekbed, but are theorized to have been wetter during other periods.

The distance between Mound Group 2 and the settlement at Dubulay is approximately $7.5 \mathrm{~km}$. Mound Group 2 is near the western edge of the Dubulay Ranch property, approximately $4 \mathrm{~km}$ east of the Kaikuchen Creek mounds, which were tested in 2011. Furthermore, the mound group itself extends further to the north, and likely into the forest to the northwest, although these areas were not captured during our kite survey of the area. More extensive mapping of the savannah will provide better information about the boundaries, and sizes of these mound fields, while more technology, such as LIDAR (which has the capability to penetrate tree cover) might be necessary to identify mounds inside the forested areas.

\section{ii. Mound Group 3}

Mound Group 3 represents the agricultural mounds most closely associated with the excavations at Dubulay, at approximately $3.5 \mathrm{~km}$ to the northwest, and across a drainage that has been impacted by modern ranching activities. Despite the setting of Mound Group 3 on an opposing drainage from Dubulay, we assume that if the mounds here were agricultural, and used during a time period overlapping with occupations at Dubulay, that these would likely have served as agricultural fields to service those populations. The intervening area east of the creek was also mapped, but was found to be absent of mounds, which highlights the selective nature of mound locations in this region. Given the spacing between Mound Group 3 and the mound sites across Wiruni Creek, it seems likely that future archaeological research will identify other settlements 
closer to Mound Group 3, as well as affiliation with occupation sites along Wiruni Creek at Matara and Red Hill.

\section{e) Red Hill Mound Group}

Red Hill mounds are located north of Dubulay Ranch, along the Wiruni creek. By boat, the distance to travel between the areas is $20 \mathrm{~km}$, although over land, the distance is roughly $10 \mathrm{~km}$ (Figure 5). It is approximately $6 \mathrm{~km}$ west of the Matara group and 5-6 km NW of Mound Group 3. The mounds at Red Hill are located primarily on the eastern face of the hill, as it slopes down to the depression that was becomes a drainage during the wet season and may have been a creek during wetter climatic conditions.

\section{f) Matara Mound Group}

The Matara mound group is located approximately $1.0 \mathrm{~km}^{2}$ northeast of Fort Nassau, which is located $10.5 \mathrm{~km}$ away from Dubulay Ranch when travelling by boat, but over land, the sites are $6.5 \mathrm{~km}$ apart. In 1991, nearly 1000 similar mounds were counted, one of which was radiocarbon dated to ca. 1860 BP from a cross-section trench excavated by Simon and Whitehead (Whitehead, et al. 2010). The Matara mounds represent the most extensive mound groups we encountered, covering at least 85 hectares, and possibly more than a full square kilometer (Figure 6). However, due to poor wind conditions on our only day to work there, we were unable to get complete coverage of this vast area. However, Matara also represents one of the most well-preserved mound sites. Furthermore, the discovery of ceramic remains at the site in 2011, make it the most likely to contain an associated village or settlement very nearby and is therefore one of the highest priorities for additional investigation during future research. Interestingly, the site features a forest island, which have been proposed to be associated with Amerindian settlements due to the increased fertility of soils left behind human occupations.

\section{g) Kaikuchen Mound Group}

As elsewhere in the study area, mounds near Kaikuchen Creek (5-6 km west of the Dubulay site) are situated along the slopes immediately adjacent small tributaries and adjacent occupation sites in savanna areas. Testing in Kaikuchen evaluated a range of potentially anthropogenic features in the savanna including agricultural mounds, forest islands, and one occupation site (Sandy Ridge). One mound measuring $15 \mathrm{~m}$ in diameter was bisected, and bulk sediment samples were collected from each $10 \mathrm{~cm}$ of the profile, the lowest sample of which included small charcoal fragments that returned a basal $(90-100 \mathrm{~cm})$ age estimate of ca. 3250 BP. A $1-x-1-m$ test unit was excavated approximately $1050 \mathrm{~m}$ north/northeast of the mound bisection (Figure 7).

\section{Discussion: Analysis of Mound PATTERNing}

One of the goals of the 2014 participatory research was to confirm that the mounds were manmade, and not the result of ant hills, which is a commonly held belief by many local people in the region. This observation is likely attributable to a feature of anthropogenic landscapes is South America wherein certain insect species inhabit former agricultural mounds and serve to maintain the structure of human constructed earthworks, as explained by McKey, et al. (2010). A number of contextual clues and archaeological evidence support the interpretation of human creation of these fields of mounds, which are linked to specific archaeological occupation sites in both time and space, however the role of humans in creation and function of the mounds is still uncertain.

The patterning and spacing of the mound clusters and the regularity with which they are found in particular types of locations was investigated in the region surrounding Dubulay, a known early residential location. During the course of mapping the mounds in 2014, the crew observed that mound groups tended to be sited on landforms that slope down to existing streams or seasonally dry stream beds. Additional analysis was conducted to evaluate additional characteristics of the anthropogenic landscapes, particularly aspects of terrain and hydrology. These were used to develop hypotheses about the relationships of mound groups to archaeological sites and landscape features. Spatial analysis of mound patterning was conducted using the nearest neighbor function in GIS, which is designed to test of the likelihood that mounds were randomly distributed over the study area, and whether the distribution conforms to a dispersed or clustered pattern if nonrandom.

McKey and Renard (McKey, et al. 2014; McKey, et al. 2010; Renard, et al. 2012a; Renard, et al. 2012b) provide ample discussion of natural factors responsible for or contributing to common earthen features of the landscape attributed to human manufacture, which were also likely tied to climate related environmental change in these transitional environments. The creation and use of the small, round mounds must be considered against the backdrop of the diversity and prominence of earthen features across both forested areas along major rivers and streams and savannah areas, including ADE middens, linear mounds, round domestic platforms with a low enclosing ditch and expanded or contracted, and the monumental construction at Dubulay. These significant and enduring features of the built environment, suggest that the small, round mounds were also important resources for indigenous plant management, including manioc, as known historically, and other plants that would benefit from the enhanced growing conditions on the mounds. The association of 
specific mound areas to well dated archaeological sites, the setting of mound sites with respect to slope and local hydrology, the spacing between mound sites, and the spacing between mounds within those sites supports the conclusion that these features were anthropogenic.

We used a $30 \mathrm{~m}$ global SRTM DEM to analyze slope and construct a hydrology model of the study area. From this it was possible to project the extent of river systems during the height of rainy season, and it became clear the most sterile sandy soils can be found in these often-dry drainage basins, and the abutting grasslands that slope above them tend to contain the mounds we suspect were managed by mid-Holocene populations. The mound fields tend to be located on gently sloping landforms, ranging from 1-4 degrees of slope. When compared to a random selection of mound locations in the study area, our analysis showed that the selection of this range of slopes was nonrandom.

The distance between the various agricultural mounds mapped, and the excavations at Dubulay Ranch, which proved to represent an approximately 5000-year-old village site, suggests that additional village sites are likely to be associated with the agricultural mounds, particularly Mound Group 2, Red Hill Mounds, and Matara Mounds, all of which are between 7 and $10 \mathrm{~km}$ from the Dubulay excavations. The distance between any two mound groups rarely exceeds $5 \mathrm{~km}$ and appears to have a tendency toward 4 $\mathrm{km}$ between mound groups. For example, the five sites mapped south of the Wiruni Creek, Dubulay, the Linear Mounds, and Mound Group 3 form an equilateral triangle, $4 \mathrm{~km}$ on each side. Mound Group 2 is almost exactly $4 \mathrm{~km}$ west of the Linear mounds, and Kaikuchen is another $4 \mathrm{~km}$ west of Mound Group 2. Given the pattern of $4 \mathrm{~km}$ intervals between mound groups, it is possible to predict the location of further mound groups and villages, as well as additional connection between the mapped mound groups. The spacing of mounds in Mound Group 2, 3, Redhill, and Matara, was analyzed using the average nearest neighbor function in GIS, which revealed a less than 1\% chance that the mounds were randomly distributed, and that they conformed to a dispersed pattern.

\section{Conclusion}

The findings from the Dubulay sites and other sites in the middle Berbice River contribute to growing consensus that the forested landscapes of Amazonia were substantially transformed by fairly large Amerindian populations. This raises doubt about claims of sparse human populations and ephemeral impacts on the natural forest environment, as suggested from many lowland forests and, in particular, Guiana shield tropical forests in the absence of systematic archaeological survey and testing (e.g., Barlow, et al. 2012; McMichael, et al. 2012; Mittermeier, et al. 2003; Piperno, et al. 2015). Mid-Holocene occupations affiliated with Dubali complex extend across the transitional tropical forest and coastal hinterland interface from Suriname to the middle Orinoco. These occupations significantly extend the antiquity of human interventions associated with more settled communities in the region, including ADE, mound-building and ceramic technology, and had an unexpectedly pronounced anthropogenic footprint in this mosaic tropical forest setting. The Mid-Holocene settled communities initiated a trajectory of landscape domestication that expanded in the late Holocene times, including semi-intensive management systems described in the $17^{\text {th }}$ century Berbice and described for many other tropical forest settings, which were mutually sustaining of tropical forest in these transitional areas settings (Clement, et al. 2010).

Inter-disciplinary and multi-cultural collaborative research strategies that address centennial- and millennial-scale data suggest that contemporary tropical forests are complex and highly textured palimpsests of human-natural interactions reflecting the strategies of active human agents (Carson, et al. 2014; Dull, et al. 2010). Our findings suggest dynamic change and socioecological systems, including substantial intra- and inter-regional variation across the humid forests of Amazonia (Balée 2010; Balée and Erickson 2006; Clement, et al. 2015; Denevan 2001; Heckenberger and Neves 2009; McEwan, et al. 2001; Roosevelt 2013), which prompt caution in broad extrapolations from minimally classified orbital imagery and minimal exploratory sampling, which do not address the remarkable heterogeneity and change within regions across Amazonia. The research contributes to global comparisons of pre-modern systems of forest management and human modification of species and eco-system biodiversity, often ignored in depictions of natural biodiversity of the Guiana shield (Balée 2010). Initial settled life and concomitant changes in technology and built environment appear during the mid-Holocene climatic optimum in transitional environments in northern and southern Amazonia, including early domestication and cultivated plants (Hilbert et al. 2017; Iriarte et al. 2020). The domesticated landscapes of the coastal hinterland transitional forests suggest alternative conversion strategies to extensive clear-cutting. The return to untended (fallow) forests from the $16^{\text {th }}$ to $18^{\text {th }}$ century contributed to the "Little IceAge" as large settled populations were decimated by disease and colonial oppression (Denevan 1996).

Mid-Holocene occupations affiliated with the Dubali complex and other similar complexes across the transitional tropical forest and coastal hinterland interface from Suriname to the middle Orinoco, had an unexpectedly pronounced anthropogenic footprint in this mosaic transitional tropical forest. These 
communities were not only uniquely adapted to the tropical forest but potentially mutually sustaining of transitional lowland tropical forest settings, particularly sensitive to climate fluctuations and human influence. These early occupations established an enduring cultural frontier between settled groups of the northern Guiana piedmont and coastal lowlands and often smaller-scale and more mobile upland groups within regional networks.

The six-millennial history of the Middle Berbice underscores the fact that contemporary tropical forests are complex and highly textured palimpsests of humannatural interactions reflecting the strategies of active human agents (Erickson and Balée 2006). They document sophisticated systems of land management uniquely adapted to the tropical ecology, which is often ignored in depictions of the biodiversity of the Guiana shield (Willis, et al. 2004). The culture history and historical ecology of these settled populations, including sophisticated systems of indigenous land management uniquely adapted to the tropical ecology of these areas, therefore has vital implications for current debates in biodiversity, ecological resilience and sustainable development, including forest restoration in transitional ecological settings, as well as pride of place among native peoples, including cultural heritage rights (Denevan 1996; Staver, et al. 2011). Through our participation with the local communities, over several years, and the cooperation of team of cultural anthropologists and archaeologists, this research helps to bring some evidence to bear on the local disagreement, as well as furthers our understanding of settlement trajectory and early agricultural strategies of pre-colonial Arawak groups in the region. Further resolution of these deep cultural histories has important implications for current debates in biodiversity, ecological resilience and sustainable development, as well as pride of place among native peoples, including cultural heritage rights.

\section{ACKNOWLEDGMENTS}

Investigations were supported by the US National Science Foundation, including preliminary investigations (8/2009; OCE 092370), primary fieldwork reported here (7-8/2011; BCS 1022537), and participatory mapping and ethnoecology (9/13-6/15; BCS 1323876). The project was sponsored by the University of Guyana (UG) and the Guyana Ministry of Culture, Youth and Sports (MCYS). Numerous individuals contributed to the field project, including UF graduate students, and UG undergraduates and over a dozen local assistants. Support from the indigenous community of Matara was critical to research reported here. In Guyana, Alex Mendes, Joseph Singh, Alim Hosein, Jenny Wishart provided valuable insights on the research, as did Minister Frank Anthony (MCYS). Numerous individuals contributed to the field project in Guyana, including Marcus Cuffy, Trevon Baird, Andrew Campbell, Leyperth King, Tedroy King Jr., and Kurleigh King. In addition, Joseph Singh, and Reard Elias were particularly helpful in supporting the project. The project was first developed by Dr. Neil L. Whitehead (UWisconsin; NSF Co-PI) and George Simon, who are posthumously acknowledged for their critical contributions to the research reported here. Finally, David Firman made significant contributions by helping to design the kite based data collection strategy, and advising on data analysis.

The ASTER V03 GDEM was retrieved from the online Data Pool, courtesy of the NASA Land Processes Distributed Active Archive Center (LP DAAC), USGS/Earth Resources Observation and Science (EROS) Center, Sioux Falls, South Dakota, https:// Ipdaac.usgs.gov/data_access/data_pool".

\section{TABLES}

Table 1: Radiocarbon dates for Dubulay and related sites along Middle Berbice River.

\begin{tabular}{|c|c|c|c|c|}
\hline Lab \# & $\begin{array}{l}\text { Area/Provenience/ } \\
\text { Context/Affiliation }\end{array}$ & $\begin{array}{l}\text { Depth } \\
\left(\mathrm{cmbd}^{\star \star}\right)\end{array}$ & $\begin{array}{l}\text { Conv. }{ }^{14} \mathrm{C} \\
\text { age }\end{array}$ & $\begin{array}{l}2 \Sigma \text { Age Range } \\
\text { (mid-point) }\end{array}$ \\
\hline $\begin{array}{l}\text { Beta- } \\
\text { 305502* }\end{array}$ & $\begin{array}{l}\text { Locus 1: N } 966 \text { W 998; N mound peak (upper); Late } \\
\text { Dubali I complex }\end{array}$ & $86 \mathrm{~cm}$ & $\begin{array}{l}4070+/-30 \\
\mathrm{BP}\end{array}$ & $\begin{array}{l}\text { Cal BP } 4790-4440 \\
\quad(4615)\end{array}$ \\
\hline $\begin{array}{l}\text { Beta- } \\
305503\end{array}$ & $\begin{array}{l}\text { Locus 1: N } 966 \text { W 998; N mound peak (upper); Late } \\
\text { Dubali I complex }\end{array}$ & $180-190 \mathrm{~cm}$ & $\begin{array}{l}4120+/-30 \\
\mathrm{BP}\end{array}$ & $\begin{array}{l}\text { Cal BP } 4820-4530 \\
\quad(4675)\end{array}$ \\
\hline $\begin{array}{l}\text { Beta- } \\
306369\end{array}$ & $\begin{array}{l}\text { Locus 1: N } 966 \text { W 998; N mound peak (upper); Late } \\
\text { Dubali I complex }\end{array}$ & $360-370 \mathrm{~cm}$ & $\begin{array}{l}4160+/-40 \\
\mathrm{BP}\end{array}$ & $\begin{array}{l}\text { Cal BP } 4840-4540 \\
\quad(4690)\end{array}$ \\
\hline $\begin{array}{l}\text { Beta- } \\
265991\end{array}$ & $\begin{array}{l}\text { Locus 1: } 2009 \text { Test Pit: N mound peak; Late Dubali I } \\
\text { complex }\end{array}$ & $130-140 \mathrm{cmbs}$ & $\begin{array}{l}4290+/-50 \\
\mathrm{BP}\end{array}$ & $\begin{array}{l}\text { Cal BP 4960-4820 } \\
\text { (4890) }\end{array}$ \\
\hline
\end{tabular}




\begin{tabular}{|c|c|c|c|c|}
\hline $\begin{array}{l}\text { Beta- } \\
305505\end{array}$ & $\begin{array}{l}\text { Locus 1: N } 1002 \text { W 996; just W of mound; Dubali ॥ } \\
\text { complex }\end{array}$ & $80-90 \mathrm{~cm}$ & $\begin{array}{l}3050+/-30 \\
\mathrm{BP}\end{array}$ & $\begin{array}{l}\text { Cal BP } 3350-3210 \\
(3280)\end{array}$ \\
\hline $\begin{array}{l}\text { Beta- } \\
305506\end{array}$ & $\begin{array}{l}\text { Locus 2: N } 1393 \text { W 1197: ADE area; Early Dubali I } \\
\text { complex }\end{array}$ & $93-95 \mathrm{~cm}$ & $\begin{array}{l}5330+/-40 \\
\text { BP }\end{array}$ & $\begin{array}{l}\text { Cal BP 6270-5990 } \\
(6130)\end{array}$ \\
\hline $\begin{array}{l}\text { Beta- } \\
265990\end{array}$ & Locus 2: 2009 Test Pit: non-ADE; Early Dubali I complex & $60-70 \mathrm{cmbs}$ & $\begin{array}{l}4330+/-80 \\
\mathrm{BP}\end{array}$ & $\begin{array}{l}\text { Cal BP } 5570-4710 \\
(5140)\end{array}$ \\
\hline $\begin{array}{l}\text { Beta- } \\
305507\end{array}$ & $\begin{array}{l}\text { Locus 2: N } 1390 \text { W 1319: non-ADE; Early Dubali I } \\
\text { complex }\end{array}$ & $60-70 \mathrm{~cm}$ & $\begin{array}{l}5030+/-40 \\
\mathrm{BP}\end{array}$ & $\begin{array}{l}\text { Cal BP 5990-5660 } \\
(5825)\end{array}$ \\
\hline $\begin{array}{l}\text { Beta- } \\
305508\end{array}$ & $\begin{array}{l}\text { Hitia Test Pit 1: riverbank ADE midden; Late Dubali I } \\
\text { complex }\end{array}$ & $80-90 \mathrm{~cm}$ & $\begin{array}{l}4170+/-40 \\
\mathrm{BP}\end{array}$ & $\begin{array}{c}\text { Cal BP } 4840-4570 \\
(4705)\end{array}$ \\
\hline $\begin{array}{l}\text { Beta- } \\
305509\end{array}$ & $\begin{array}{l}\text { Kaikuchen Trench 1; large circular mound; Dubali II/Post- } \\
\text { Dubali complex }\end{array}$ & $90-100 \mathrm{~cm}$ & $\begin{array}{l}3030+/-30 \\
\mathrm{BP}\end{array}$ & $\begin{array}{c}\text { Cal BP 3340-3160 } \\
(3250)\end{array}$ \\
\hline
\end{tabular}

Notes:

* palm fruit, all others are wood charcoal;

${ }^{* *} \mathrm{cmbd}=\mathrm{cm}$ below datum (arbitrary vertical control point); $\mathrm{cmbs}=\mathrm{cm}$ below actual ground surface

\section{FIGURES}

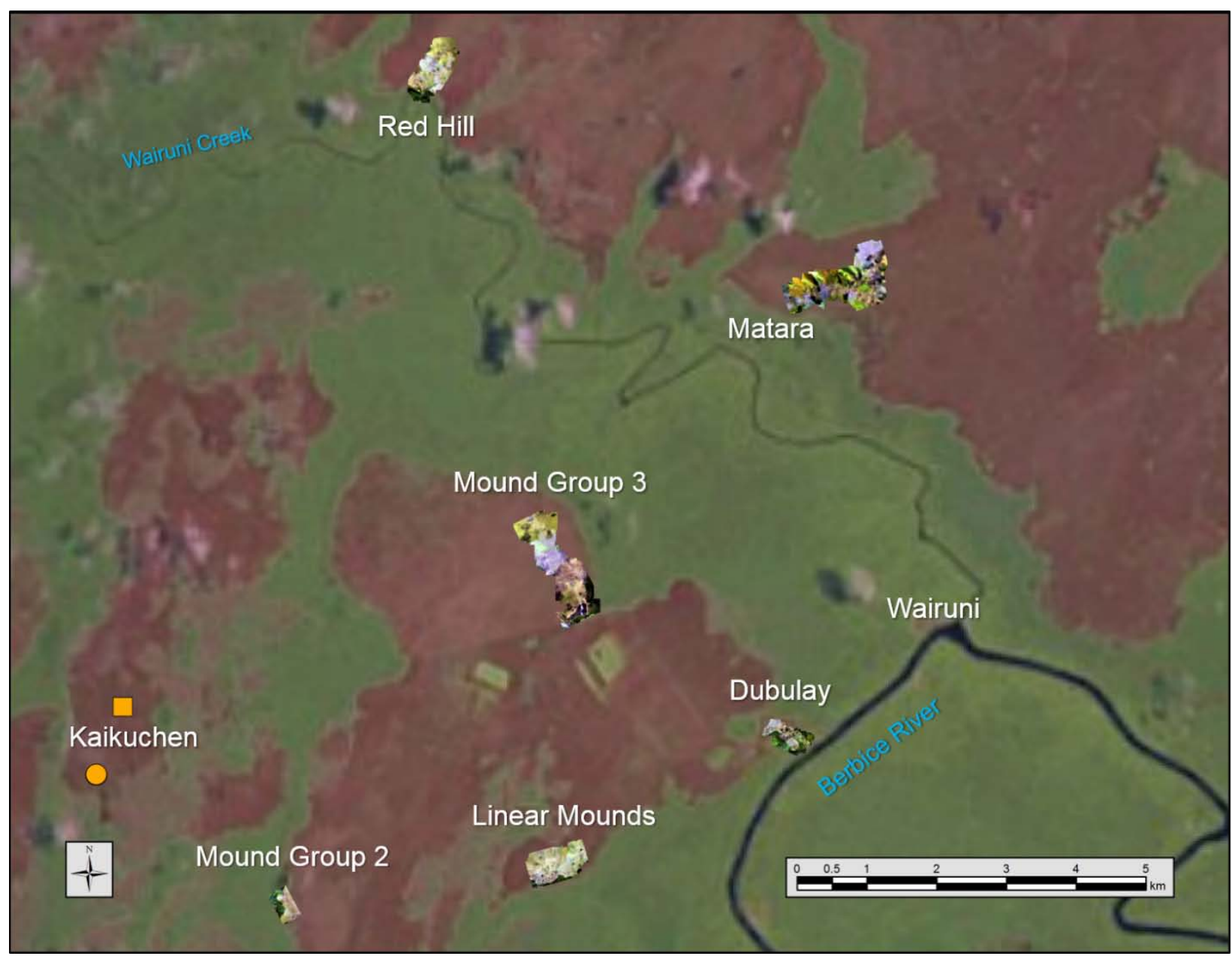

Figure 1: Map of Study Area with areas of kite-mapping coverage associated with the principle site of Dubulay and surrounding mound complexes to the south of Wiruni Creek and Matara and Red Hill sites to the north. 


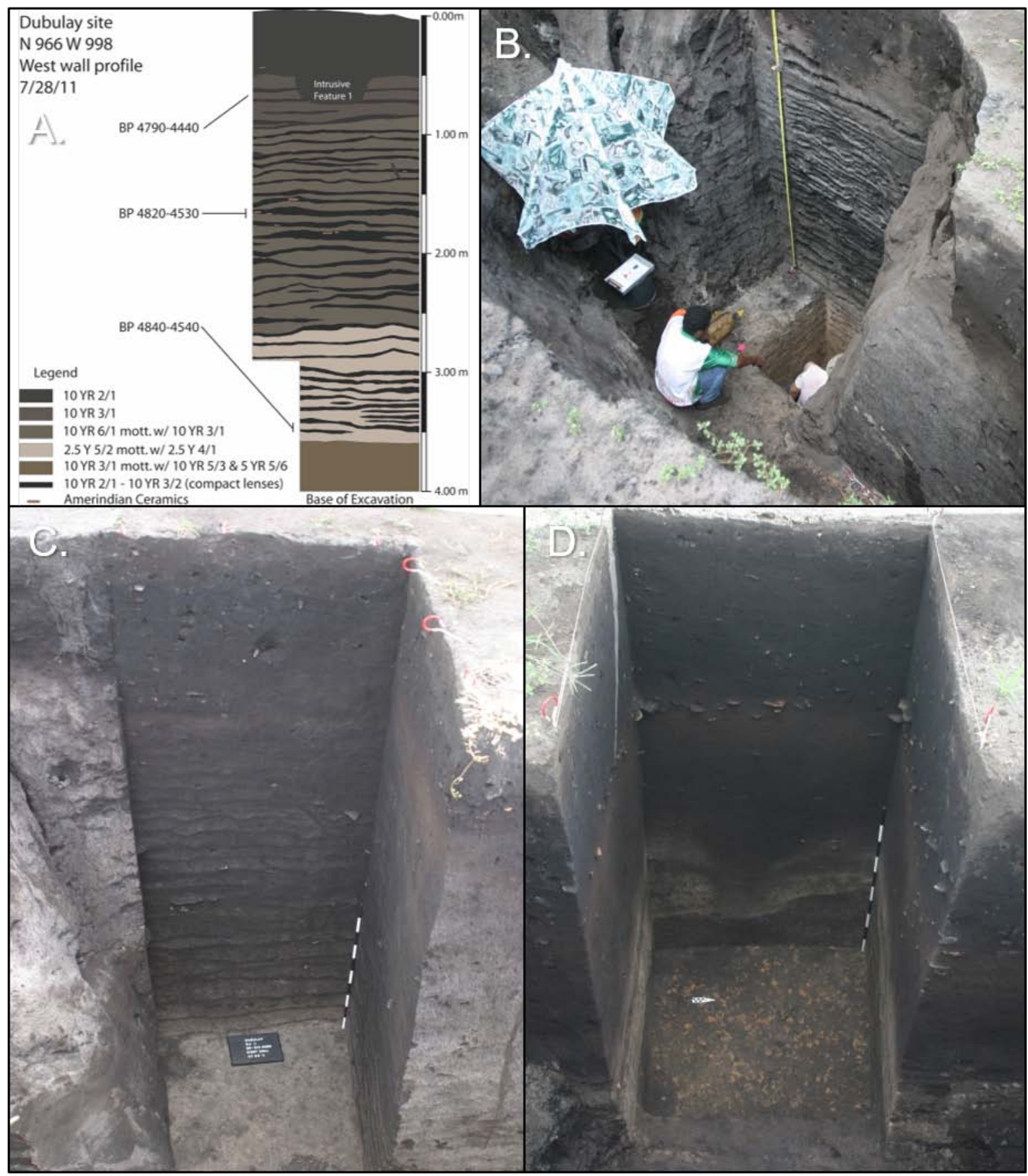

Figure 2: A. Schematic of mound 1 profile with radiocarbon dates; B. Overview photo of mound 1 post-excavation collection of soil samples by micro-stratigraphic unit; C. N996W998 during excavation (note partially slumped north wall); D. N978W998 during excavation. 

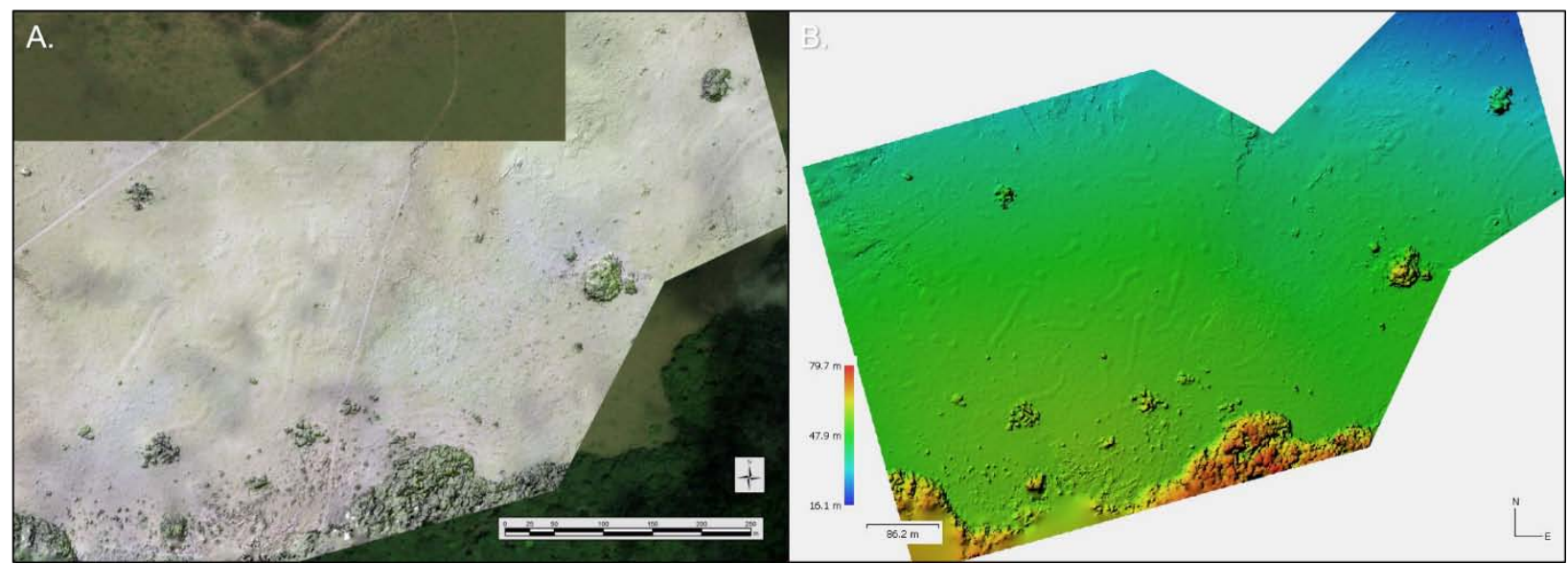

Figure 3: Linear Mound Group. A. Geo-referenced orthomosaic; B. Digital Elevation Model in photoscan.

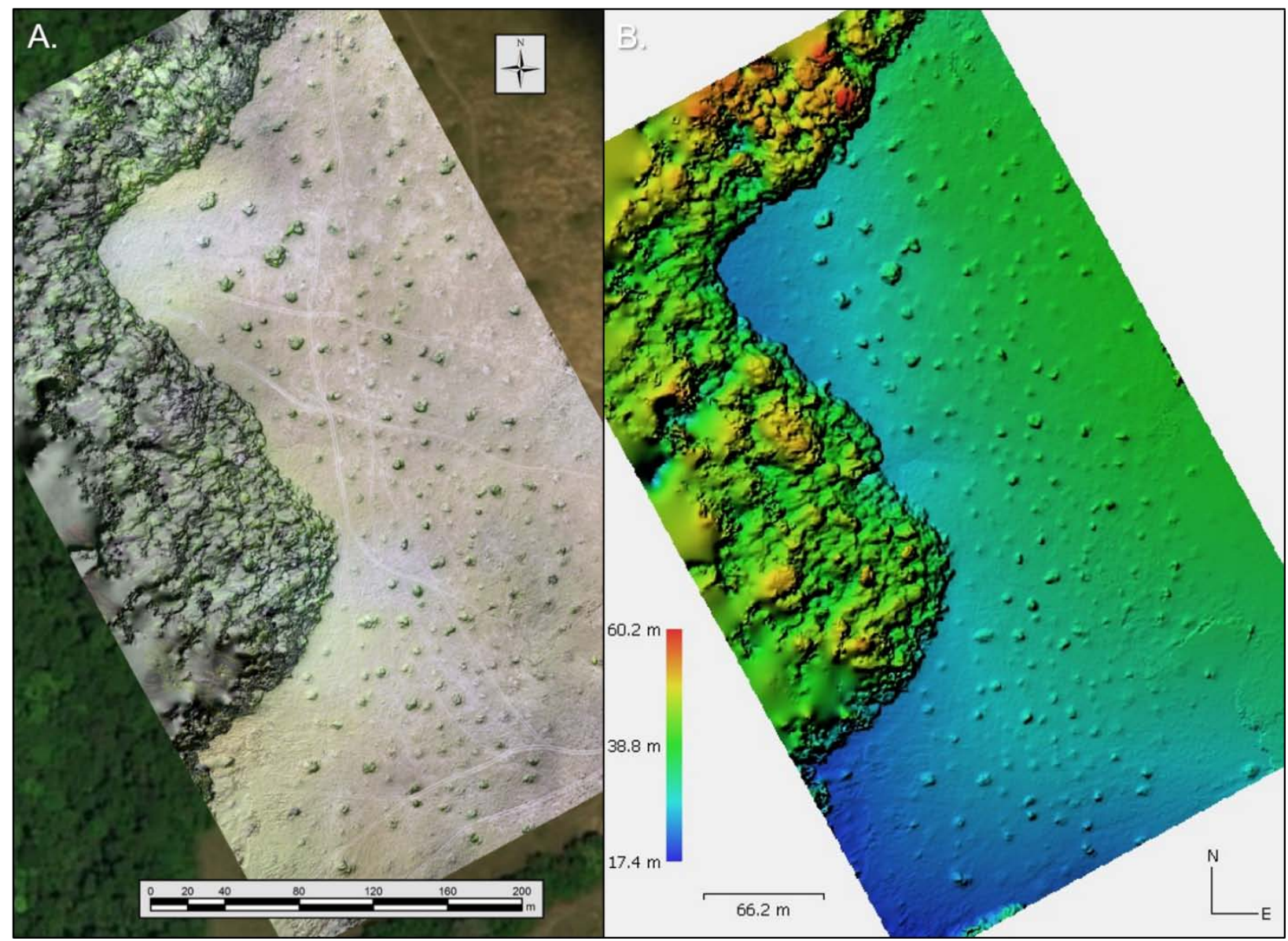

Figure 4: Mound Group 2. A. Geo-referenced orthomosaic; B. Digital Elevation Model in photoscan. 


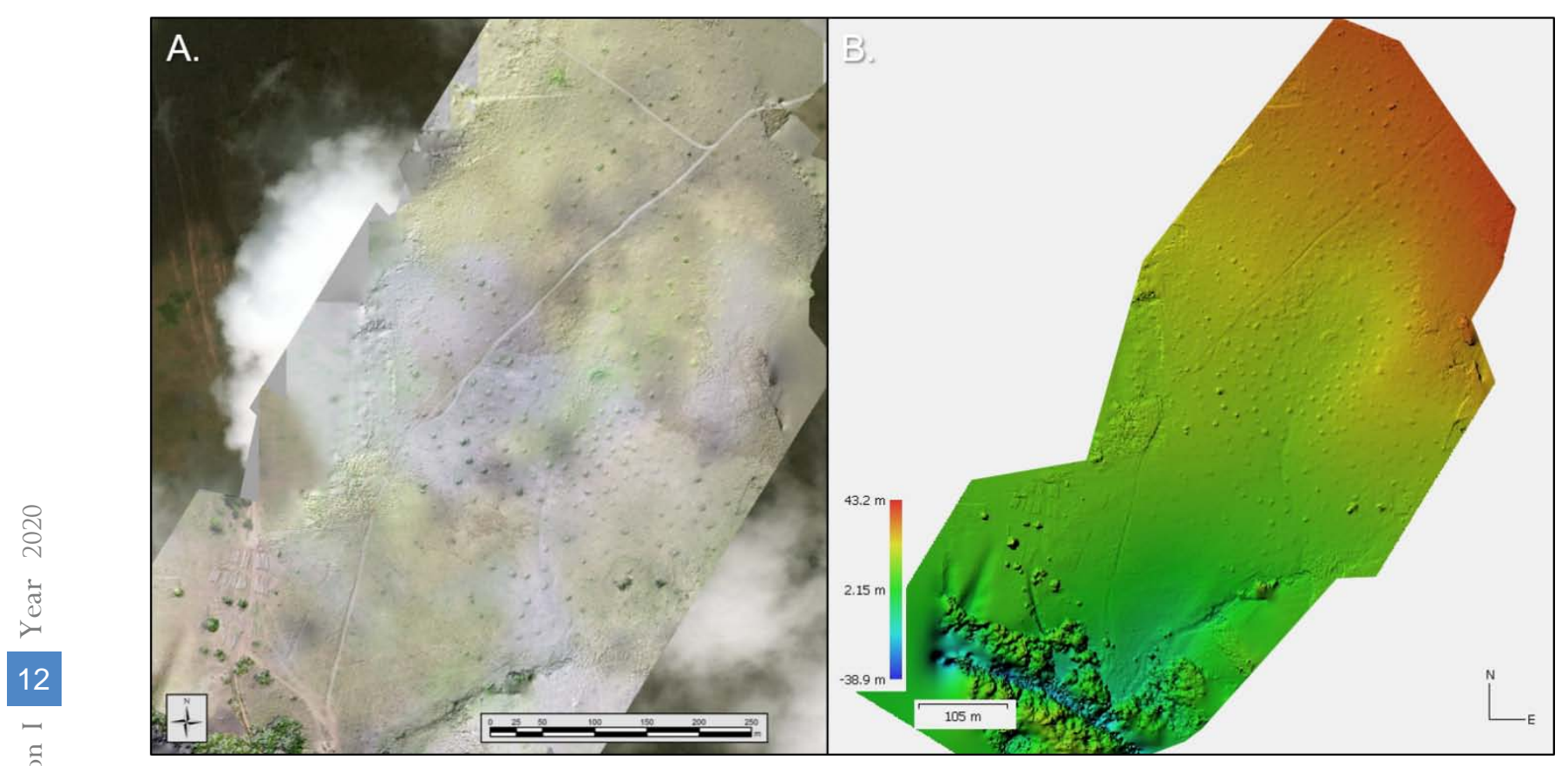

Figure 5: Red Hill Mound Group. A. Geo-referenced orthomosaic; B. Digital Elevation Model in photoscan.

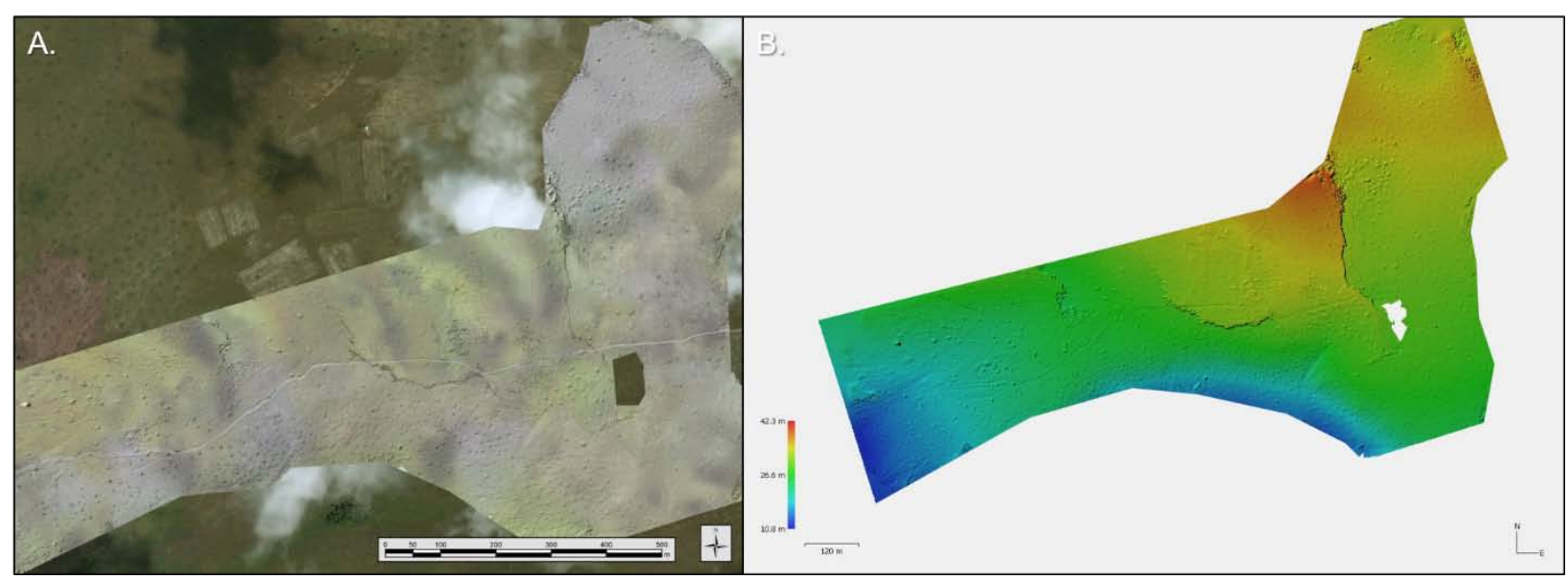

Figure 6: Matara Mound Group. A. Geo-referenced orthomosaic; B. Digital Elevation Model in photoscan. 


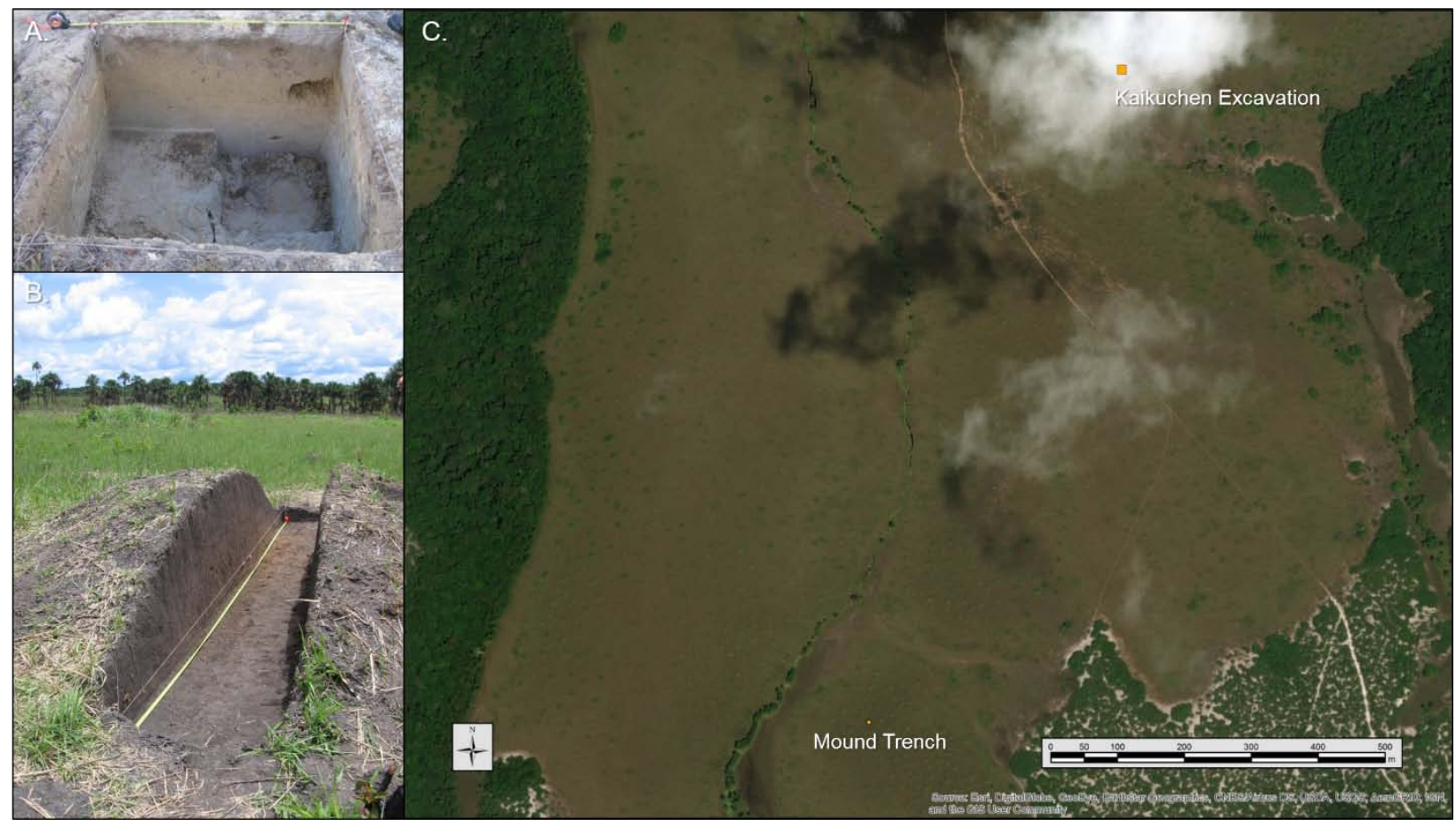

Figure 7: A. Kaikuchen excavation showing open cavity in SW corner (upper right) were ceramic concentration was encountered at $20-30 \mathrm{~cm}$ below ground surface corresponds to; B. Kaikuchen mound trench bisection (carbonized botanical remains from a column sample returned a date of $3030+/-30$ BP from 90-100 cm below ground surface); C. Map of Kaikuchen Area.

\section{References Cited}

1. Aber, James S, Susan W Aber, and Firooza Pavri 2002 Unmanned Small Format Aerial Photography From Kites Acquiring Large-Scale, High-Resolution, Multiview-Angle Imagery. International Archives of Photogrammetry Remote Sensing and Spatial Information Sciences 34(1):1-6.

2. Arroyo-Kalin, Manuel 2010 The Amazonian formative: Crop domestication and anthropogenic soils. Diversity 2(4): 473-504.

3. Balée, William L. 2010 Long-term anthropic influences on the diversity of amazonian land scapes and biota. Diversity, Special Issue. Basel, Switzerland.

4. Balée, William L., and Clark L. Erickson 2006 Time and complexity in historical ecology: studies in the neotropical lowlands: Columbia University Press.

5. Barlow, Jos, Toby A. Gardner, Alexander C. Lees, Luke Parry, and Carlos A. Peres 2012 How pristine are tropical forests? An ecological perspective on the pre-Columbian human footprint in Amazonia and implications for contemporary conservation. Biological Conservation 151(1): 45-49.

6. Burger, Richard L., and Robert M. Rosenswig 2012 Early New World Monumentality. Gainesville: University Press of Florida.

7. Carson, John Francis, Bronwen S. Whitney, Francis E. Mayle, José Iriarte, Heiko Prümers, J. Daniel Soto, and Jennifer Watling 2014 Environmental impact of geometric earthwork construction in preColumbian Amazonia. Proceedings of the National Academy of Sciences 111(29): 10497-10502.

8. Clement, Charles, Michelly De Cristo-Araújo, Geo Coppens D'Eeckenbrugge, Alessandro Alves Pereira, and Doriane Picanço-Rodrigues 2010 Origin and Domestication of Native Amazonian Crops. Diversity 2(1): 72

9. Clement, Charles R., William M. Denevan, Michael J. Heckenberger, André Braga Junqueira, Eduardo G. Neves, Wenceslau G. Teixeira, and William I. Woods 2015 The domestication of Amazonia before European conquest. Proceedings of the Royal Society B: Biological Sciences 282 (1812).

10. Denevan, William M. 1996 A Bluff Model of Riverine Settlement in Prehistoric Amazonia. Annals of the Association of American Geographers 86 (4): 654-681.

11. - 2001 Cultivated landscapes of Native Amazonia and the Andes: triumph over the soil. Oxford, UK New York: Oxford University Press.

12. - 2003 Semi-intensive Pre-European Cultivation and the Origins of Anthropogenic Dark Earths in Amazonia. In Amazonian Dark Earths: Explorations in Space and Time. B. Glaser and W.I. Woods, eds. Pp. 135-43. Berlin: Springer.

13. Dull, Robert A., Richard J. Nevle, William I. Woods, Dennis K. Bird, Shiri Avnery, and William M. Denevan 2010 The Columbian Encounter and the Little Ice Age: Abrupt Land Use Change, Fire, and 
Greenhouse Forcing. Annals of the Association of American Geographers 100(4): 755-771.

14. Erickson, Clark L, and William Balée 2006 The historical ecology of a complex landscape in Bolivia. Time and complexity in historical ecology: Studies in the Neotropical Lowlands: 187-233.

15. Evans, Clifford, and Betty Meggers 1960 Archeological investigations in British Guiana. Washington,: U.S. Govt. Print. Off.

16. Flannery, Kent, ed. 1976 The early Mesoamerican village. New York: Academic Press.

17. Heckenberger, Michael J., George Simon, J. Christian Russell, and Neil L. Whitehead 2012 Berbice Archaeology Project: Report on 2011 Investigations. the Amerindian Research Unit, Department of Anthropology, University of Guyana and the Ministry of Culture, Youth, and Sport, Georgetown, Guyana, Department of Anthropology and Land-Use and Environmental Change Institute, University of Florida.

18. Heckenberger, Michael, and Eduardo Góes Neves 2009 Amazonian Archaeology. Annual Review of Anthropology 38(1): 251-266.

19. Iriarte, Jose, Sarah Elliott, S. Yoshi Maezumi, Daiana Alves, Regina Gonda, Mark Robinson, Jonas Gregorio de Souza, Jennifer Watling, and Josephine Handley 2020 The origins of Amazonian landscapes: Plant cultivation, domestication and the spread of food production in tropical South America. Quaternary Science Reviews 248: 106582.

20. Iriarte, José, Bruno Glaser, Jennifer Watling, Adam Wainwright, Jago Jonathan Birk, Delphine Renard, Stéphen Rostain, and Doyle McKey 2010 Late Holocene Neotropical agricultural landscapes: phytolith and stable carbon isotope analysis of raised fields from French Guianan coastal savannahs. Journal of Archaeological Science 37(12): 2984-2994.

21. Lathrap, Donald W. 1977 Our mother the cayman, our father the gourd: Spinden revisited or a unitary model for the emergence of agriculture in the New World. In Origins of Agriculture. C. Reed, ed. Pp. 713-51. The Hague: Mouton.

22. McEwan, Colin, Cristiana Barreto, and Eduardo Neves, eds. 2001 The unknown Amazon. Nature in culture in ancient Brazil. London: British Museum Press.

23. McKey, Doyle, Delphine Renard, Anne Zangerlé, Jose Iriarte, Kisay Adame, Elena Suarez Jimenez, Axelle Solibiéda, Mélisse Durécu, Marion Comptour, Stéphen Rostain, and Christine Raimond 2014 New approaches to pre-Columbian raised-field agriculture: the ecology of seasonally flooded savannas, and living raised fields in Africa, as windows on the past and future.

24. McKey, Doyle, Stéphen Rostain, José Iriarte, Bruno Glaser, Jago Jonathan Birk, Irene Holst, and
Delphine Renard 2010 Pre-Columbian agricultural landscapes, ecosystem engineers, and selforganized patchiness in Amazonia. Proceedings of the National Academy of Sciences 107 (17): 7823-7828.

25. McMichael, C. H., D. R. Piperno, M. B. Bush, M. R. Silman, A. R. Zimmerman, M. F. Raczka, and L. C. Lobato 2012 Sparse Pre-Columbian Human Habitation in Western Amazonia. Science 336 (6087): 1429-1431.

26. Mittermeier, R. A., C. G. Mittermeier, T. M. Brooks, J. D. Pilgrim, W. R. Konstant, G. A. B. da Fonseca, and C. Kormos 2003 Wilderness and biodiversity conservation. Proceedings of the National Academy of Sciences 100(18): 10309-10313.

27. Oliver, José R 2008 The archaeology of agriculture in ancient Amazonia. In The Handbook of South American Archaeology. Pp. 185-216: Springer.

28. Pachauri, Rajendra K, Myles R Allen, Vicente $R$ Barros, John Broome, Wolfgang Cramer, Renate Christ, John A Church, Leon Clarke, Qin Dahe, and Purnamita Dasgupta 2014 Climate change 2014: synthesis report. Contribution of Working Groups I, II and III to the fifth assessment report of the Intergovernmental Panel on Climate Change: Ipcc.

29. Piperno, Dolores R, Crystal McMichael, and Mark B Bush 2015 Amazonia and the Anthropocene: What was the spatial extent and intensity of human landscape modification in the Amazon Basin at the end of prehistory? The Holocene 25(10):1588-1597.

30. Piperno, Dolores R., and Deborah M. Pearsall 1998 The origins of agriculture in the lowland neotropics. San Diego: Academic Press.

31. Plew, Mark G 2005 The archaeology of Guyana: Archaeopress.

32. Posey, D. A., and W. Balée, eds. 1989 Resource management in Amazonia: Indigenous and folk strategies. New York: New York Botanical Garden.

33. Prado, Luciane, Illaina Wainer, Christiano Chiessi, Marie-Pierre Ledru, and Bruno Turcq 2013 A midHolocene climate reconstruction for eastern South America.

34. Renard, D, J Iriarte, JJ Birk, S Rostain, B Glaser, and D McKey 2012a Ecological engineers ahead of their time: The functioning of pre-Columbian raisedfield agriculture and its potential contributions to sustainability today. Ecological Engineering 45: 30-44.

35. Renard, Delphine, Jago Jonathan Birk, Bruno Glaser, José Iriarte, Gilles Grisard, Johannes Karl, and Doyle McKey 2012b Origin of mound-field landscapes: a multi-proxy approach combining contemporary vegetation, carbon stable isotopes and phytoliths. Plant and Soil 351(1): 337-353.

36. Roosevelt, A. C., R. A. Housley, M. Imazio da Silveira, S. Maranca, and R. Johnson 1991 Eighth 
Millennium Pottery from a Prehistoric Shell Midden in the Brazilian Amazon. Science 254(1621-1624).

37. Roosevelt, Anna C. 1995 Early pottery in the Amazon. Twenty years of scholarly obscurity. In The emergence of pottery. W.K. Barnett and J.W. Hoopes, eds. Pp. 115-31. Washington and London: Smithsonian Institution Press.

38. - 2013 The Amazon and the Anthropocene: 13,000 years of human influence in a tropical rainforest. Anthropocene 4: 69-87.

39. Rostain, Stéphen 2008a Agricultural Earthworks on the French Guiana Coast. In Handbook of South American Archaeology. H. Silverman, and William Isbell, ed. Pp. 217-233. New York: Springer.

40. - 2008b The Archaeology of the Guianas: An Overview. In Handbook of South American Archaeology. H. Silverman, and William H. Isbell, ed. Pp.? New York: Springer.

41. - 2010 Pre-Columbian Earthworks in Coastal Amazonia. Diversity 2(3): 331.

42. -2012 Islands in the rainforest: Landscape management in pre-Columbian Amazonia. Walnut Creek, California: Left Coast Press.

43. Schaan, Denise P. 2012 Sacred Geographies of Ancient Amazonia: Historical ecology of social complexity,. New Frontiers in Historical Ecology Vol. 1.

44. Shearn, Isaac, Michael Heckenberger, and George Simon 2017 Ceramic Innovation at Dubulay, an Early Agricultural Village in the Middle Berbice, Guyana. Archaeology and Anthropology 21: 4-19.

45. Silva Dias, Pedro L., Bruno Turcq, Maria Assunção F. Silva Dias, Pascale Braconnot, and Tatiana Jorgetti 2009 Mid-Holocene Climate of Tropical South America: A Model-Data Approach. In Past Climate Variability in South America and Surrounding Regions: From the Last Glacial Maximum to the Holocene. F. Vimeux, F. Sylvestre, and M. Khodri, eds. Pp. 259-281. Dordrecht: Springer Netherlands.

46. Silva, Lucas CR, Gabriel D Vale, Ricardo F Haidar, and Leonel da SL Sternberg 2010 Deciphering earth mound origins in central Brazil. Plant and Soil 336(1-2): 3-14.

47. Staver, A. Carla, Sally Archibald, and Simon A. Levin 2011 The Global Extent and Determinants of Savanna and Forest as Alternative Biome States. Science 334 (6053): 230-232.

48. Whitehead, Neil L., Michael J. Heckenberger, and George Simon 2010 Materializing the past among the Lokono (Arawak) of the Berbice River, Guyana. Antropológica 54 (114): 87-127.

49. Williams, Denis 2003 Prehistoric Guiana. Kingston, Jamaica: Ian Randle Publishers.

50. Willis, K. J., L. Gillson, and T. M. Brncic 2004 How "Virgin" Is Virgin Rainforest? Science 304(5669): 402-403.
51. Woods, William I, Wenceslau G Teixeira, Johannes Lehmann, Christoph Steiner, Antoinette Winkler Prins, and Lilian Rebellato 2009 Amazonian dark earths: Wim Sombroek's vision: Springer.

52. Woods, William I., and Joseph M. McCann 1999 The Anthropogenic Origin and Persistence of Amazonian Dark Earths. Yearbook, Conference of Latin Americanist Geographers 25: 7-14. 